\title{
Dyskeratosis Congenita: A Rare Case Report
}

\author{
Roy $\mathbf{B}^{1}$, Mondal $\mathbf{G}^{2}$, Paul $\mathrm{D}^{3}$, Kalam $\mathrm{A}^{4}$, Basu $\mathrm{K}^{5}$ \\ 1Dr. Banasree Roy, MBBS, DCH, MD, R.M.O. cum \\ Clinical Tutor, Dr. B.C.Roy Postgraduate Institute of \\ Paediatric Sciences, Kolkata 70054, West Bengal, \\ India, ${ }^{2}$ Dr. Gobinda Mondal, MBBS, MD, Assistant \\ Professor, Department of Paediatric Medicine, Burdwan \\ Medical College, West Bengal, India, ${ }^{3}$ Dr. Dilip Kumar \\ Paul, MBBS, MD. Medical Superintendent cum Vice \\ Principal, Dr. B.C. Roy Postgraduate Institute of \\ Paediatric Sciences, Kolkata 70054, West Bengal, India, \\ ${ }^{4}$ Dr. Abul Kalam, MBBS, MD, Assistant Professor, Dr. \\ B.C.Roy Postgraduate Institute of Paediatric Sciences, \\ Kolkata 70054, West Bengal, India, ${ }^{5}$ Dr. Kausambi \\ Basu, MBBS,DCH. Senior Resident, Dr. B.C.Roy \\ Postgraduate Institute of Paediatric Sciences, Kolkata \\ 70054, West Bengal, India.
}

\section{The Case}

A seven year old Hindu boy born out of Anonconsanguineous marriage presented with recurrent febrile episodes for last two months and nonspecific symptoms like pallor, lethargy and poor scholastic performance for more than a month.

Examination revealed pallor, few hyperpigmented macules over face (Fig. 1) \& limbs, dystrophic nails in all four limbs. Mucosal leucoplakia was present in tongue only (Fig.2). Buccal and oropharyngeal mucosa were not affected.

Finger nails (Fig 3) were involved more than toe nails (Fig.4). All kind of changes like ridging, splitting, progressive atrophy, thinning, pterygium formation, rudimentary nails were present.

Patient gives history of excessive lacrimation without any reddening or irritation of eyes. Patient had no respiratory problem. Examination of abdomen revealed no organomegaly. Testes were palpable bilaterally; genitourinary system examination was within normal limits.

There was no family history of skin and hematological disorders.

\section{Address for correspondence \\ Dr. Banasree Roy \\ E-mail: drbr1978@rediffmail.com}

This work is licensed under a Creative Commons Attribution 3.0 License.

\begin{abstract}
Dyskeratosis congenita is a rare congenital disorder affecting mainly the integumentary system. It is a progressive disease with involvement of bone marrow. A triad of hyperpigmentation, nail dystrophy and leucoplakia are characteristic of this disease.
\end{abstract}

Key words: Hyperpigmentation, nail dystrophy, leucoplakia

\section{Investigation}

Blood picture was suggestive of anemia with hemoglobin level of $6.7 \mathrm{~g} / \mathrm{dl}$; thrombocytopenia, platelet count being 30000 though patient had no spontaneous bleeding from any site. Total leukocyte count was 3400 with $45 \%$ polymorphs, $32 \%$ lymphocyte, $10 \%$ band cell and $12 \%$ monocyte and $1 \%$ eosinophil. Peripheral blood smear showed anisocytic hypochromic anemia with macro platelets. Reticulocyte count was $1.3 \%$. Direct comb test, $\mathrm{Hb}$ electrophoresis, serum iron level, total iron binding capacity were normal. Liver function tests, renal function tests were normal.

Patient had an IQ of 60 . Chest $X$ ray was normal. $X$ ray spine and hip were done to find out any scoliosis, avascular necrosis of femur. Only mild osteoporotic changes were noticed. USG abdomen revealed no abnormality.

Bone marrow aspiration study from iliac crest reveled bone marrow hypoplasia, decreased megakaryocytes and RBC precursor in marrow. Skin biopsy report can be mentioned in detail here.

Patient was offered supportive treatment. Patient was also treated with antibiotic. Platelet and packed RBC were transfused when platelet count fell below $20000 / \mathrm{cmm}$ and $\mathrm{Hb} \%$ was $4.2 \mathrm{gm} \%$. Erythropoietin and granulocyte colony stimulating factor injections were also given.

\section{How to cite this article ?}

Roy B, Mondal G, Paul D, Kalam A, Basu K. Dyskeratosis Congenita: A Rare Case Report. J Nepal Paediatr Soc 2013;33(3):223-226. 


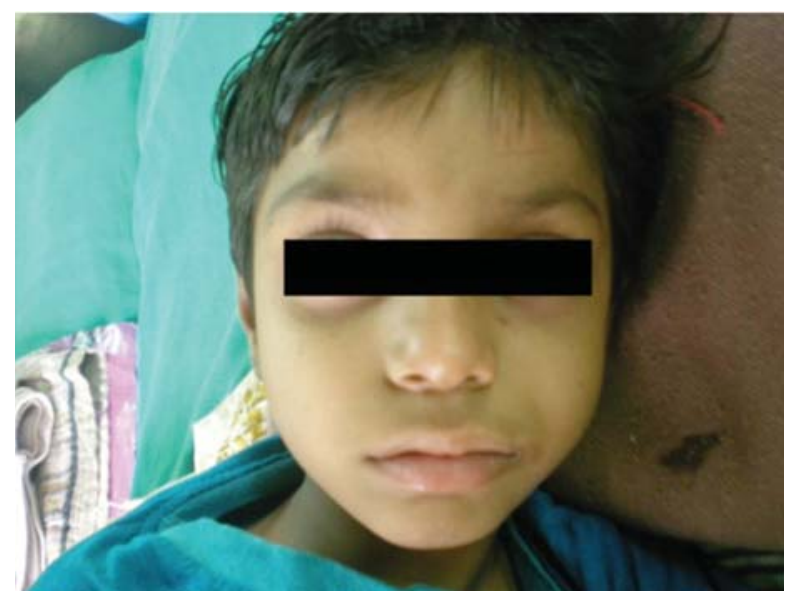

Fig 1: Pallor with hyperpigmented macule

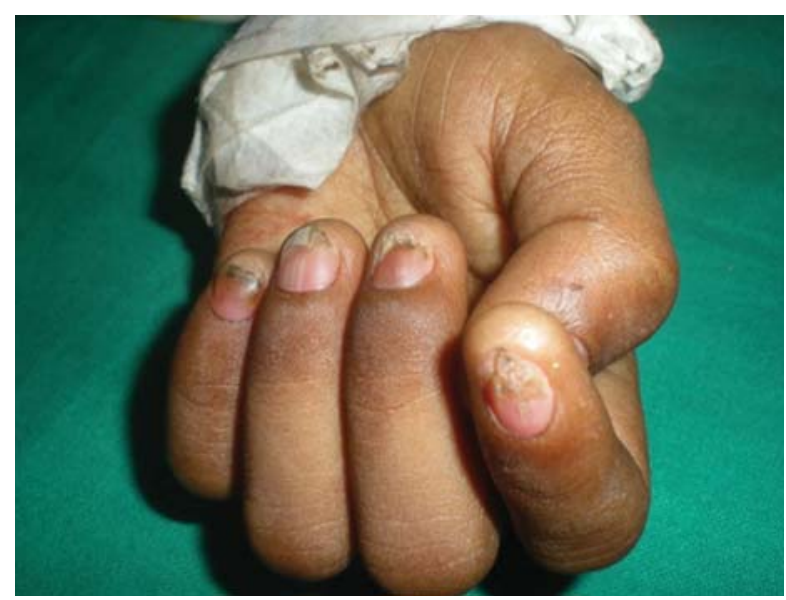

Fig 3: Nail changes of fingers

\section{Discussion}

Dyskeratosis congenita (DKC) is also called Zinsser-Cole-Engman syndrome ${ }^{1}$. It is an inherited disorder of the mucocutaneous and haematopoietic systems in association with somatic abnormalities ${ }^{2}$. The exact prevalence of dyskeratosis congenita is unknown. It is estimated to occur in approximately 1 in 1 million people ${ }^{3}$. Skin and nail findings become apparent in the first 10 years whereas oral leucoplakia is seen later. The manifestations tend to progress as the patient grows older.

Patients develop aplastic anemia about $50 \%$ cases. It is also considered to be a premalignant condition ${ }^{4}$. Male to female ratio is $13: 1^{5}$. Up to $85 \%$ of cases are inherited as $X$ linked recessive form and rest $15 \%$ is either autosomal dominant or recessive forms. Major protein affected is dyskerin. These mutations affect telomerase activity ${ }^{6}$.

Abnormal skin pigmentation is one of the prominent findings. Hypo or hyperpigmented macules or patches in a motteled or reticulate fashion are found. It is mainly found in sun exposed areas of skin. Alopecia of scalp may

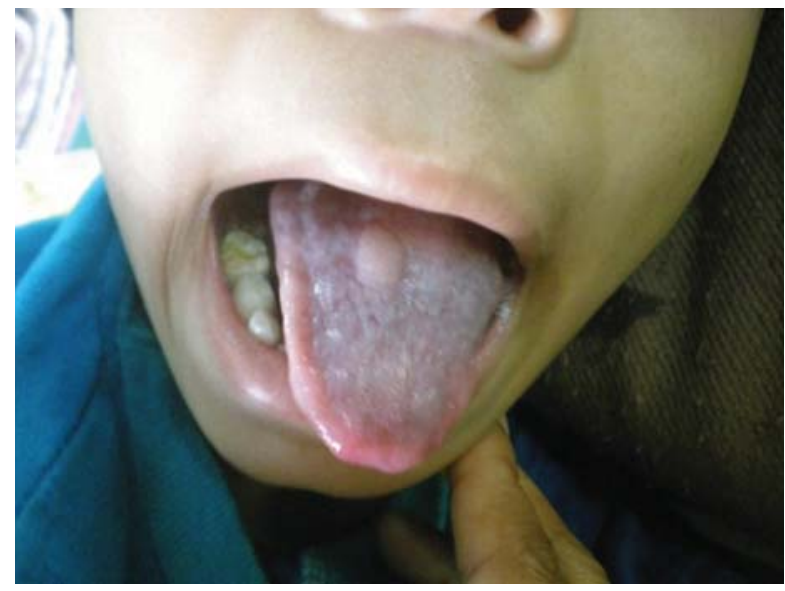

Fig 2: Leucoplakia of tongue

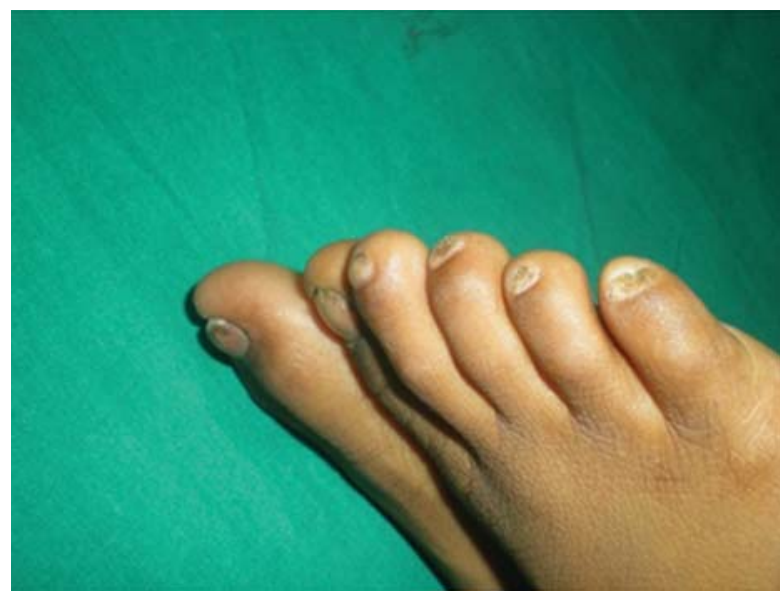

Fig 4: Nail changes of toes

be associated ${ }^{7}$. In our patient only few hyperpigmented macules were present over face and upper limb. Typical skin changes were absent, so skin biopsy revealed only mild increase in melanin in dermis.

Mucosal leucoplakia occurs in approximately $80 \%$ of patients and typically involves the buccal mucosa, tongue, and oropharynx $x^{7}$. In our case leucoplakia was present over the tongue.

Approximately $90 \%$ of affected individual have peripheral cytopenia of one or more lineages. In some cases, this is the initial presentation as in our case, with a median age of onset of 10 years. Bone marrow failure is a major cause of death. Approximately $20 \%$ of individuals with DKC develop pulmonary complications, including pulmonary fibrosis and abnormalities of pulmonary vasculature ${ }^{8}$.

Patients have an increased prevalence of malignant mucosal neoplasms, particularly squamous cell carcinoma of the mouth, nasopharynx, esophagus, rectum, vagina, or cervix. These often occur within sites of leucoplakia. The prevalence of squamous 
cell carcinoma of the skin is also increased. Other malignancies reported include Hodgkin lymphoma, adenocarcinoma of the gastrointestinal tract, and bronchial and laryngeal carcinoma ${ }^{9}$. Malignancy tends to develop in the third decade of life. Patients may have learning difficulties and mental retardation. In our case no malignancy was detected.

DKC reportedly is associated with conjunctivitis, blepharitides, and pterygium. Lacrimal duct stenosis resulting in epiphora ${ }^{9}$ occurs in approximately $80 \%$ of patients and it was one of the problems in presented case. Patients may have mandibular hypoplasia, osteoporosis, avascular necrosis, ${ }^{10}$ and scoliosis. But only generalized osteoporotic changes were detected in present case.

Gastrointestinal system involvement may include esophageal webs, hepatosplenomegaly, enteropathy; cirrhosis and genitourinary system involvement like hypo spastic testes, hypospadias, and ureteral stenosis are occasionally found ${ }^{11}$. These findings were absent in our case.

Sufferers of DKC have been shown to have a reduction in telomerase RNA component (TERC) levels invariably affecting the normal function of telomerase which maintains these telomeres. ${ }^{12,13,14}$ TERC levels down, telomere maintenance during development suffers accordingly

Genetic tests help identify the DKC1 gene mutation. Flow-FISH analysis can distinguish affected cases due to the very short telomeres compared to age-matched controls ${ }^{15}$. But this test was out of our scope.

There is no definite cure at this time for dyskeratosis congenita. Treatment is aimed at maintaining bone marrow function as this is the major cause of death. Few options are 1. Oxymetholone - an anabolic steroid that helps bone marrow function in two-thirds of patients for several years. 2. Haematopoietic growth factors - erythropoietin, granulocyte macrophage colonystimulating factor and granulocyte colony-stimulating factor. 3. Bone marrow transplant from an unaffected family member or from unrelated donor with less aggressive pre-transplant therapy ${ }^{16,17,18}$.

Although dyskeratosis congenita would seem to be an ideal condition for gene therapy, no progress has been made in this direction yet. Genetic counseling is important for the planning of future pregnancies. Ante-natal diagnosis has been achieved successfully. Since the DKC1 gene mutation has been associated with dyskeratosis congenita, individuals in the family of a person affected by the disorder can have genetic testing, and females who are carriers of the defective gene can be identified. An infant at risk for inheriting the disorder can be tested prenatally or after birth, allowing for early diagnosis and treatment respectively.

Our patient was discharged in afebrile condition. Parents were counseled for bone marrow transplantation. All the family members were screened by physical examination and peripheral blood picture.

\section{Conclusion}

Dyskeratosis congenita may present with pancytopenia initially before marked skin changes. It is important to consider the diagnosis in cases of bone marrow failure where no other cause has been identified and oral leucoplakia in a young person with no history of tobacco use and in early onset cancers.

\section{References}

1. James, William; Berger, Timothy; Elston, Dirk Andrews' Diseases of the Skin: Clinical Dermatology. 10th ed. Philadelphia: WB Saunders 2005.

2. Arnold HL, Odom RB, James WD. Some genodermatosis. In: Arnold HL, Odom RB, James WD, eds. Andrew's diseases of the skin. 8th edn. Philadelphia: WB Saunders, 1990:674.

3. Nishio N,Kojima S. Recent Progress in Dyskeratosis Congenita. Int J Hematol 2010;92:419-424.

4. Saunders. Melvin H Freedman: The Constitutional Pancytopenias In: Nelson Textbook of pediatric; Elsevier, 18th edition 2008;2050-51.

5. Ogden GR, Connor E, Chisholm DM. Dyskeratosis congenita: report of a case and review of the literature. Oral Surg Oral Med Oral Pathol 1988;65(5):586-591.

6. Redkar N,Pandey DB, Jerajani HR, Padhiyar R, Dhokare A. Dyskeratosis congenita with Portal Hypertension of Unknown Etiology. J Assoc Phy India 2011;59:260.

7. Atkinson J. C., Harvey K. E., Domingo D. L. et al. Oral and dental phenotype of dyskeratosis congenita. Oral Diseases 2008;14(5):419-427.

8. Dokal I. Dyskeratosis congenita in all its forms. $\mathrm{Br} \mathrm{J}$ Haematol 2000;110:768-779.

9. A. Auluck. Dyskeratosis congenita. Report of a case with literature review. Medicina Oral, Patologia Oral y Cirugia Bucal 2007;12(5):E369-E373.

10. Sinha S, Trivedi V, Krishna A, Rao N. Dyskeratosis congenita Management and review of complications: A case report. Oman Med J 2013;28(4):281-284

11. Harper J. Genetics and genodermatoses. In: Champion RH, Burton JL, Ebling FJG, eds. 
Textbook of dermatology. 5th edn. Oxford: Blackwell, 1992:54-6.

12. Wason, James; et al. "Molecular Biology of the Gene. 5th ed". Annu Rev Biochem 2004 (San Francisco: Pearson Education, Inc).

13. Walne AJ, Vulliamy T, Marrone A, et al. Genetic heterogenecty in autosomal recessive dyskeratosis congenita with one subtype due to mutations in the telomerase- associated protein NOP 10. Hum Mol Genet 2007;16(13):1619-29.

14. Heiss NS, Knight SW, Vulliamy TJ, et al. "X linked Dyskeratosis congenta is caused by mutationsin a highly conserved gene with putative nuclear functions." Nat Genet 1998;19(1): 32-38.

15. Alter BP, Baerlocher GM, Savage SA, Chanock SJ, Weksler BB, Willner JP, et al. Very short telomere length by flow fluorescence in situ hybridization identifies patients with dyskeratosis congenita. Blood 2007;110(5):1439-47.

16. Erduran E, Hacisalihoglu S, Ozoran Y. Treatment of dyskeratosis congenita with granulocytemacrophage colony-stimulating factor and erythropoietin. $J$ Pediatr Hematol Oncol 2003;25(4):333-5.

17. Giri N, Pitel PA, Green D, Alter BP. Splenic peliosis and rupture in patients with dyskeratosis congenita on androgens and granulocyte colony-stimulating factor. Br J Haematol 2007;138(6):815-7.

18. Gadalla SM, Sales-Bonfim C, Carreras J, Alter BP, Antin $\mathrm{JH}$, Ayas $\mathrm{M}$, et al. Outcomes of Allogeneic Hematopoietic Cell Transplantation in Patients with Dyskeratosis Congenita. Biol Blood Marrow Transplant 2013;19(8):1238-43. 